https://doi.org/10.31470/2706-7904-2020-15-176-179

\title{
КОНСТРУКТ «МОРАЛЬНІ СУДЖЕННЯ» \\ У СТАНОВЛЕННІ САМОСВІДОМОСТІ ДОШКІЛЬНИКІВ: \\ АНАЛІЗ ПЕРВИННИХ РЕЗУЛЬТАТІВ
}

Construct «Moral Judgments» in the Formation of Self-Awareness of Preschoolers: An Analysis of Primary Results

\author{
Liubov Lokhvytska \\ Ph.D. in Pedagogy, Associate Professor \\ Hryhorii Skovoroda University in Pereiaslav (Ukraine) \\ Liubov.Lokhvytska@phdpu.edu.ua \\ https://orcid.org/0000-0001-6852-5477
}

\begin{abstract}
The analysis of primary results of realization by preschool age children of the moral norms presented in the verbal form - moral judgments is offered. Notion "moral judgments" is defined in the context of considering the cognitive component of moral consciousness. On the basis of the conducted methods «History», «Conversation» (modified by G. Uruntayeva and Y. Afonkina) the average indicators on the sample on all scales regarding children's understanding of the essence of the following 12 moral qualities: «kindness», «anger», «lying», «honesty», "generosity», «greed», «rudeness», «politeness», «sensitivity», «cruelty», «boastfulness» and «modesty» are determined. The obtained results demonstrated that the majority of senior preschoolers, expressing moral and evaluative judgments, have a vocabulary that nominates moral concepts. According to the method «Story drawings» (modified by the same authors) the levels of children's awareness of moral qualities and the ability to determine morality in specific life situations based on verbalization of the essence of moral events are determined.
\end{abstract}

Key words: moral judgments, self-awareness, preschoolers, verbalization.

\section{Ветуп \\ Introduction}

Одним із пріоритетних завдань сьогоденної дошкільної освіти, що визначено державним стандартом, є здійснення соціально-морального розвитку дітей (Базовий компонент дошкільної освіти, 2012). Означене потребує з'ясування специфіки перебігу процесу морального зростання особистості дошкільника, який має безпосередній стосунок до опанування й усвідомлення ним моральних норм і правил, 
формування вмінь контактувати 3 довколишніми та виявляти емоційне ставлення до них, а також продукувати моральне поводження. Успішність морального розвитку в дошкільному віці залежить від вдало організованого морального виховання. Зокрема, спираючись на дослідження відомого українського психолога I. Беха, можемо стверджувати, що специфіка зазначеного процесу залежить від становлення в особистості моральної самосвідомості, як його головної детермінанти (Бех, 2015). За науковою традицією визначаємо мету проведеного наукового пошуку: проаналізувати первинні результати усвідомлення старшими дошкільниками моральних норм, що фіксувалося як висловлювання ними моральних суджень. Останні трактуємо вербальним обрамленням оцінного ставлення, що формується на основі наявних у дитини моральних знань, що презентується у вербальній формі. Отже, власне сам конструкт «моральні судження» конотується нами в контексті розгляду когнітивного компонента моральної самосвідомості особистості.

\section{Методи та методики дослідження Methods and Techniques of the Research}

Задля реалізації поставленої мети були застосовані методики «Історії», «Бесіда» та «Сюжетні малюнки» (у модифікації Г. Урунтаєвої та Ю. Афонкіної, 2013) для визначення розуміння моральних якостей та усвідомлення їх сутності дошкільниками, що виражалося ними у вербальній формі - моральних судженнях. До експериментальної роботи було задіяно 210 дітей старшого дошкільного віку з різних регіонів України (Київської обл., Полтавської обл. і Черкаської обл.).

\section{Результати \\ Results}

Узагальнюючи отримані дані за проведеною методикою «Icmopï̈», було виявлено, що найбільша кількість (61.8\%) дітей показала середній рівень розуміння тлумачення моральних якостей i, відповідно, володіння словниковим запасом, щодо опису їх сутності. Найбільш зрозумілими для пояснення дітьми виявилися такі моральні якості: «доброта», «щедрість», «злість», «чесність», «брехливість» та «жорстокість». Складнішими для дітей були - «чуйність», «жадібність», «неввічливість» та «ввічливість». Дошкільникам було важче мотивувати оцінку щодо проявів зазначеного переліку моральних якостей, вони обмежувалися лише назвою останніх (22.3\%). Найнижчим рівнем (15.9\%) розуміння в досліджуваних виявилися такі моральні якості: «хвастливість» та «скромність», що пояснювалося таким 
фактом, що діти не могли вирізнити зазначені моральні якості або неправильно їх диференціювали, вони відчували труднощі, коментуючи відповідні моральні ситуації.

Результати, отримані за методикою «Бесіда» (модифікація Г. Урунтаєвої та Ю. Афонкіної), яка проводилася 3 метою вивчити сформованість у старших дошкільників узагальнених образів певних моральних якостей (як стійкого емоційного образу, узагальненого за суттєвими ознаками) та оцінно-етичних суджень, засвідчили, що найбільша частка припадає на обізнаність дітей про такі моральні якості: «добро», «зло», «чесність», «брехливість, «щедрість» та «жадібність» (59.2\%). Старші дошкільники виявляють знання про належне («добро») і неналежне («зло»), при цьому здатні аргументувати зазначені поняття, наводити конкретні приклади 3 повсякденного життя про їх прояви в поводженні людей, аналізувати моральну поведінку персонажів літературних творів, мультфільмів та ін. Менш сформованими (24.4\%) виявилися уявлення досліджуваних про моральні якості «ввічливість», «неввічливість», «чуйність» та «жорстокість». У дітей виникали труднощі в їх обгрунтуванні, наведенні прикладів 3 власного досвіду. Найнижчою (16.6\%) зафіксовано сформованість обізнаності дітей про моральні якості «скромність» та «хвастливість», як і в попередній методиці «Історії».

За методикою «Сюжетні малюнки» проводили діагностику усвідомлення дитиною моральних якостей та іiі уміння визначати і описувати моральні прояви поведінки в конкретних життєвих ситуаціях, супроводжуючи власним оцінним ставленням. За отриманими результатами $23.3 \%$ із кількості дітей, які брали участь в експерименті, неправильно розкладали малюнки, на яких зображені як позитивні, так і негативні вчинки (складали разом) при цьому не називали моральну якість; 30.1\% дітей правильно розкладали малюнки, але не могли обгрунтувати власні дії, моральну якість не називали; 26.7\% старших дошкільників правильно розкладали малюнки, обгрунтовували власний вибір, але не називали моральну якість і $19.9 \%$ дітей правильно розкладали малюнки, обгрунтовуючи групування зображеного сюжету на добрі і недобрі вчинки, та оперували знаннями про сутність моральних якостей, правильно називаючи їх.

\section{Висновки \\ Conclusions}

Отже, на підставі проведеного аналізу первинних результатів усвідомлення дітьми старшого дошкільного віку моральних норм, що продукується у формі моральних суджень, можемо стверджувати, що пояснення сутності основних моральних якостей залежить від діапазону моральних знань дітей, їхнього 
Psycholinguistics in a Modern World - 2020. Proceedings of the 15th International Scientific and Practical Conference (Pereiaslav-Khmelnytskyi, 22-23 October, 2020)

словникового запасу (частин мови), вміння сформулювати власну думку тощо. Старші дошкільники висловлюють морально-оцінні судження, визначаючи прояви моральності в конкретних життєвих ситуаціях, коли в них належно розвинена функція мовленнєвої діяльності, що сприяє, передусім, поповненню власного лексикону поняттями, які номінують норми, правила морального поводження в соціумі, ознаки емоційно-морального стану довколишніх та особливості взаємостосунків, а також використовувати слово для регуляції своєї моральної поведінки.

Перспективи подальшої експериментальної роботи полягатимуть у з'ясуванні специфіки розвитку моральних суджень в дітей середнього дошкільного віку, який більшість зарубіжних психологів вважають сенситивним у цьому процесі.

\section{Література \\ References}

Базовий компонент дошкільної освіти (нова редакція). (2012). А.М. Богуш (Наук. кер.). Київ:

Спецвип. журн. «Вихователь-методист дошкільного закладу».

Бех, І.Д. (2015). Зростити моральну особистість - головна турбота. Дошкільне виховання, 4, 6-8.

Методики «Історії», «Бесіда», «Сюжетні малюнки» (модифікований варіант методики

Г. Урунтаєвої та Ю. Афонкіної). (2013). Практичний психолог: дитячий садок, 2, 31-33. 